\title{
North Carolina Library Association Minutes of The Executive BoARd
}

\author{
Friday, April 16, 2004 \\ New Hanover County Public Library \\ Wilmington, North Carolina
}

\begin{abstract}
Attending: Caroline Walters, Ross Holt, Lisa Sheffield, Beth L. Rowe, Bryna Coonin, Claudia Gollop, Keith Burkhead, Teresa Wehrli, Susan Neilson, Bao-Chu Chang, Jean Rick, John Via, Robert Burgin, Pauletta Bracy, Bobby C. Wynn, Gale Greenlee, Annie Wu substituting for Sue J. Williams, Marie Spencer substituting for Priscilla Lewis, Loree Kelly substituting for Carol Laing, Dale Cousins, David Paynter, Mary Hatcher, Catherine L. Wilkinson, Gerald Holmes, Jenny Barrett, Irene Laube, Robert James, and Connie Keller.
\end{abstract}

\section{Call to Order and Welcome:}

The meeting was called to order at 10:10 a.m. by President Pauletta Bracy at the New Hanover County Public Library. The Board was welcomed to the New Hanover County Public Library by David Paynter and Mary Hatcher.

\section{Minutes of January 16, 2004}

Minutes of the January 16, 2004 meeting were approved with the addition of John Via to the list of attendees.

\section{President's Report:}

Biennium Agenda:

President Bracy updated the four points of the biennium agenda as follows:

1. Infrastructural Integrity

President Bracy reported that she had received the most of the committee memberships and the communication liaisons for the round tables, sections, and committees. Also discussed was creating a more prominent location on the NCLA Web page for professional activities of the membership.

2. Strategic Planning Claudia Gollop volunteered to survey the membership and proceed with strategic planning. She will call upon us as needed and when it is time for the membership survey to be taken.

3. Organizational Outreach

Chair Brenda Stephens was not able to attend, but she reported to President Bracy that she is reviewing organizations to contact. Ross Holt and President Bracy are members of the N.C. Open Government Coalition. The coalition promotes open government issues and gives citizens and the media a place to go for assistance when they feel they aren't getting the information they need from the government. There are plans to have a Web-page link on the Charlotte Observer's Web page.

4. Centennial Conference 2004

John Via reported on progress made in planning for the Centennial Conference. The following committees and chairs are now actively planning the conference.

Susan Hertzog is program chair of the Centennial Conference Committee. Vanessa Ramseur is site manager at the Conference. Carol Jordan will coordinate tours. Kevin Cherry is in charge of the history committee. Steve Kelly from Wake Forest is chair of the exhibits. Andrea Tullos is chair of registration. Teresa Wehrli is chair of the conference store. Bao-Chu Chang is Webmistress. Judith Givens is the representative from the Southeastern Library Association (SELA). Faith Line is SELA secretary. Candy Ortman is chair of the vendors committee.

The conference will celebrate NCLA's Centennial in a joint conference with SELA. Charlotte will have a free trolley running by the time of the conference. Other sites in Charlotte to draw people are the Mint Museum, Levine Museum of the New South, tours, and shopping.

Tentative plans are for pre-conferences on Tuesday. A casual reception will be sponsored on Tuesday 
evening by the new members roundtables of both NCLA and SELA. A reception will be held Wednesday night at the Public Library of Charlotte and Mecklenburg County following a librarians' talent show. Centennial Moments presentations will occur throughout the conference. Historical photographs of librarians and libraries will be on display. On Thursday the President's Luncheon will honor all living presidents of both NCLA and SELA. Also, on Thursday, there will be a reception at Levine Museum of the New South. The Conference Committee is planning to offer a casual nightcap to watch the movie Desk Set. All during the conference the history committee will interview members and tape them and put together a video to show Friday afternoon at the close of the conference, which will be preserved for the future.

A copy of the program planning form was passed out. It is important to make clear that all audio-visual charges are at the expense of the committee providing the program.

The estimated budget for the Centennial Conference was passed out and reviewed. The Conference Store needs to be in the exhibits hall and also have a kiosk at the registration area and at the big events. Plans are for adding general merchandise to the usual cups, t-shirts, etc. Profits from exhibits will be fifty/ fifty.

The registration budget was passed out. The Board was asked to provide feedback but does not need to approve this budget. Discussion ensued about exhibit passes, different badges, policing issues, etc. Conference planning for the Westin hotel is on the Charlotte Conference Web page.

The working theme is NCLA and SELA: A Splendid Combination. Discussion followed on how to emphasize the fact that this is NCLA's Centennial year conference even though SELA is participating. Other themes were suggested.

Program ideas include the history of NCLA, aging, Hispanics, anything about what's happening in the Southeast, benchmarking against other services, technology possibilities, library buildings, staff development, and library education.

The NCLA Web page has program planning and hotel registration forms and contact information, schedules, etc.

John Via requests that we think about our history as well as our future.

President Bracy commended the efforts of the Conference Planning Committee. Planning needs to begin on the 2005 Biennial Conference. For the 2005 conference President Bracy called for diversity in speakers at these events and suggested that publicity for the conference emphasize diversity. We need to approve budget estimates for that conference.

MOTION: President Bracy suggested a motion to approve the estimated budget for the NCLA/SELA Conference 2004. The motion was made by Robert Burgin and seconded by Dale Cousins. The motion carried by a voice vote of the Board.

\section{Executive Board Orientation}

The first Executive Board orientation session was successful. Discussion led to suggestions about the organization of NCLA. Plans are to repeat the orientation as needed.

\section{ALA-NCLA Student Membership}

ALA has a program that would provide a student with membership in ALA and NCLA for \$25.00. ALA would then give NCLA half of that money. Our present student membership is $\$ 10.00$. Eleven states already have this arrangement. Teresa Wehrli says this has proved beneficial for Michigan. The feeling is that once students become members of ALA and a state association they will continue with the memberships once they have graduated.

MOTION: President Bracy called for a motion to accept an arrangement with ALA for student memberships. Ross Holt made the motion and Dale Cousins seconded it. The motion was passed by voice vote.

\section{Pay equity}

President Bracy opened discussion on selecting a special issue to address for the next biennium. One of many issues affecting librarians is pay equity. A task force will be appointed by President Bracy to meet and then report its objectives and recommendations to the Board at a future meeting. A larger issue is the need for the support of NCLA from all library systems in the state and pay equity could piggy-back on this. ALA has a toolkit for pay equity that would aid NCLA in addressing this issue. Work on the pay-equity issue would dovetail with the work of the paraprofessional section on certification and advocacy for all librarians in the state. A key issue would be to teach strategies for librarians and municipal government officials to work for salary increases for librarians.

\section{Treasurer's Report:}

The Treasurer's report is posted on the NCLA Web page.

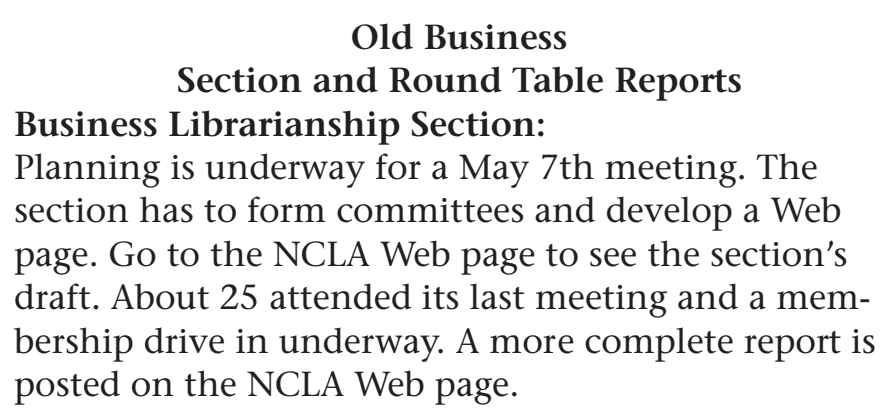

\section{Old Business} Business Librarianship Section

Planning is underway for a May 7th meeting. The section has to form committees and develop a Web page. Go to the NCLA Web page to see the section's draft. About 25 attended its last meeting and a memposted on the NCLA Web page. 
Children's Services Section:

Centennial Conference planning is the focus of the report, which is posted on the NCLA Web page.

\section{College and University Libraries Section:}

No report.

Community and Junior College Libraries Section: Centennial Conference planning is the focus of its report, which is posted on the NCLA webpage.

\section{Documents Section:}

A spring workshop is planned for May 7th. The meeting will include an update on state access to documents and the afternoon will focus on selecting a new editor and name for its newsletter. See the request for a name for the newsletter in the New Business area of the minutes.

\section{Library Administration and Management Section:} Centennial Conference planning is the focus of the report, which is posted on the NCLA Web page.

\section{N.C. Association of School Librarians:}

No report.

\section{N.C. Public Library Trustee Association:}

Mary Hatcher has a list of trustee memberships and recommends that the association should have a listserv. The association needs to get many more trustees involved. Work is progressing on a conference program dealing with how to get more money for public libraries and how to deal with local governmental bodies. Ann Marie Elkins is working on an orientation program and a brochure for trustees.

\section{Public Library Section:}

The Conference planning committee for the section will meet on April 30th. The section will sponsor an author luncheon, focus on one program rather than several, and will jointly sponsor an Interlibrary Loan program with SOLINET (Southeastern Library Network). Public library paraprofessionals will have a program as well.

\section{Reference and Adult Services Section:}

Duncan Smith will present a program at the conference. The breakfast/luncheon speaker has been chosen. The section will co-sponsor a program with SELA.

\section{Resources and Technical Services Section: No report.}

\section{Literacy Section:}

The section met March 31st to refine its focus and draft goals. The section will continue to sponsor workshops and has begun conference planning. The section won an award from Library Journal.

New Members Round Table:

No report.

\section{N.C. Paraprofessional Association:}

At the December meeting the association appointed a committee to study the state of respect between professional librarians and paraprofessionals in North Carolina. A survey was designed and the association will submit a report by midsummer. A more complete report is posted on the NCLA Web page.

\section{Round Table for Ethnic Minority Concerns:}

The round table's focus is on conference planning and pre-conference programming. REMCO's goal is to find ways to honor Roadbuilders. The REFORMA chapter will not be a part of NCLA since our by-laws prevent some of the actions they want to take. Most members of REFORMA are also members of REMCO. Compete report is on the NCLA Web page.

\section{Round Table on Special Collections:} No report.

\section{Round Table on the Status of Women in Librarianship:}

Focus of meeting was conference planning and revision of the Marilyn Miller Professional Commitment award.

\section{Technology and Trends Round Table:}

Report is on the NCLA Web page.

\section{Committee Reports}

\section{Archives:}

A request will be sent to the library schools for help with the NCLA archives. The committee needs someone to work at least once a month to bring order to the NCLA archives. The committee needs more than the current three members. The bylaws call for six members. Jean Rick has gotten work release from Meredith to go to the State Archives one day per week this summer. A full report is on the NCLA Web page.

\section{Conference 2005:}

Vice-President/President-Elect and Chair of the Conference Committee is Robert Burgin. Dale Cousins is program chair. Steve Kelly is exhibits chair. Bao-Chu Chang is Webmistress. Deborah Lambert at Wake Forest is local arrangements chair. The conference store, placement, and registration positions are still open. A theme for the 2005 conference has yet to be chosen. The committee has received several suggestions. A theme orientated toward library users instead of libraries themselves is being investigated. 
Commission on the Future of the book:

Robert Burgin reported that the spring issue of North

Carolina Libraries was put together by the commission.

Constitution, Codes and Handbook Revision:

Phil Barton and Terry Nichols are joining with Bobby Wynn to reconstruct the NCLA Handbook by comparing the 4th and 5th editions and reviewing suggestions. Some portions were updated on the NCLA Web page but not brought before this committee. The changes in the by-laws need documentation and revised wording to be correct. All old editions of the Handbook need to be collected and destroyed. The committee will have a new draft ready for approval in January 2005. Ross Holt volunteered to help the committee.

\section{Continuing Education:}

No report.

\section{Endowment:}

No report.

\section{Finance:}

The Finance Report was distributed. This is a brand new committee. The committee is planning revisions to the financial procedures. The 5 th edition has been edited to reflect what has been going on. The committee is working through perennial issues and would like feedback. The committee will look at some of Diane Kester's duties and time constraints and consider ways to divide these duties differently. Credit-card guidelines need to be created. The committee meets virtually usually and in person only at conferences.

\section{Leadership Institute:}

The committee recommends that the next NCLA Leadership Institute be held in the summer rather than in the spring or fall and Monday through Friday. The next round of speakers and mentors will be from a variety of libraries in North Carolina. Out-of-state registration is being considered for approval by the Executive Board, but not if it results in leaving out any North Carolina librarian. The committee has collected data from graduates of the institutes and is now debating how to analyze the data. Overall, the feedback has been positive. The next institute will involve more Board members and NCLA members. There will be daily evaluations throughout the institute. The committee suggested that for the Conference in 2004 there should be a panel of graduates and publicity for the next institute. Plans are being made for a reunion of the Leadership Institute graduates during the conference.

\section{Membership:}

The committee will meet May 5th. The committee will have an NCLA table at the North Carolina Learning Resources Conference in July. Teresa Wehrli would like to know of other events where the membership committee could advertise NCLA.

Draft guidelines for the social fund were distributed. Discussion followed on who should take care of the social fund. Who should send flowers, cards, etc. to members? How can we be consistent? How do we fund this? President Bracy and Teresa Wehrli will work out the details. The Executive Board will send cards, not flowers. President Bracy will send personal notes and notify everyone else. Then, individual Board members can respond as they feel necessary. There will be a post to the yahoo list to report an event that needs a personal response.

\section{Nominating:}

No report. (Clarification: 350 members get a second member on the board and an additional 200 get another voting member. The New Members Round Table is not included in this policy.)

\section{Operations:}

A report was distributed to the Board members. Irene Laube stated that the membership procedures have been streamlined as much as possible. Discussion followed around the duties of the administrative assistant, the amount of time involved in the position, and how to subdivide/add/delete the duties. One change that has made more work has been the use of more personal letters instead of form letters. The committee has previously looked at outsourcing but decided against it. Conferences take a lot of work and we will have two, back to back, in 2004 and 2005. The Operations Committee favors increasing hours of the administrative assistant. If the Finance Committee approves the additional hours, the Executive Committee of the Executive Board can approve the change.

\section{Public Policy:}

A full report is on the NCLA Web page. Capitol Strategies met with the committee. The committee has been collecting information for the North Carolina legislature about NC LIVE by a four-question survey on the impact of NC LIVE on library patrons. Ross Holt mentioned the importance of legislative champions for libraries. If you know of someone, please let Ross Holt know. The Public Library Section has an active network to get information before the legislature. Left off the membership was Kate Hickey, library director at Elon University, representing the independent colleges and universities. Legislative day is June 2nd. 


\section{Publications and Marketing:}

No report.

\section{Scholarships:}

Annie Wu substituted for Sue Williams. A full report is on the NCLA Web page. The application deadline is May 30th. The applications are reviewed in June to decide on recipients. The Scholarships Web page has been revised. The committee also needs two more members. One objective of the committee is to follow up on loans.

\section{NCLA Web Page:}

A full report is on the NCLA Web page. Check information for your section, round table, or committee to make sure the information is correct. The password will be changed. Included will be some statistics on traffic and browsers.

\section{Organizational Outreach:}

No report.

\section{Strategic Development:}

Claudia Gollop is looking at other state library associations' strategic plans and their organizational charts.

\section{North Carolina Libraries:}

\section{Other Reports}

No report.

ALA Councilor:

No report.

SELA Councilor:

No report.

\section{State Library of North Carolina:}

No report.

\section{New Business \\ Section Name-Change Request: \\ The Documents Section requested to change its name to the Government Resources Section. A report on why this change is needed was given. For the next biennium, the section would use Government Re- sources Section with the old name of Documents in parentheses.}

Motion: President Bracy called for a motion to approve the name change of the section from Documents to Government Resources Section. The motion was made by Gerald Holmes and seconded by Robert Burgin. The question was called and the motion passed by voice vote.

Organizational Chart:

Bao-Chu Chang reported that a draft of the NCLA organizational chart is on the NCLA Web page. The chart includes the Executive Committee (President, Vice President, 2 Directors at Large, Treasurer, Secretary), 11 sections, 17 round tables, and 18 committees.

\section{Use of the Logo:}

NCLA needs to have guidelines about the use of the logo on the NCLA Web page.

ADA requirements:

These need to be provided to the local arrangements committee and should also be included on the NCLA Web page.

Differences between sections and roundtables: Robert Burgin read the old NCLA minutes to provide some insight. In the early 1980s, section chairs could vote, but round table chairs could not; to be a section required 100 members and to be a round table required 25. In 1985, NCLA approved that round tables be treated the same as sections. Basically, round tables need 100 members to exist. At one time the entire NCLA Constitution was reprinted annually.

\section{Parliamentarian}

President Bracy is considering the appointment of a Parliamentarian.

\section{Announcements:}

Dale Cousins (Wake County Public Library) invited the Board to North Carolina State University for the North Carolina Literary Festival.

Robert James (Duke University) mentioned a new noncirculating library on Childhood Traumatic Stress. The library will begin offering interlibrary loan service in the spring of 2005.

There is $\$ 7000$ for project grants available to sections, round tables, and committees to help with costs for conference programs or other activities. Applications are available online.

\section{Actions Taken}

- 2004 Conference budget approved.

- ALA/NCLA joint student membership approved

- Document Section name-change request approved

Next meeting: Friday, July 16, 2004, at Meredith College at 10:00 a.m.

Adjourned at 2:38 P.M. 